\author{
LIVIO MELINA \\ Pontificio Istituto Giovanni Paolo II \\ per le scienze del Matrimonio e della Famiglia \\ Ponitificia Università Lateranense, Romaą
}

\title{
Wyzwania Amoris laetitia dla teologa moralisty
}

Adhortacja apostolska Amoris laetitia stanowi dla teologa moralisty wyzwanie bez precedensu i dotyczy różnych poziomów najnowszej historii Kościoła. Być może jedynie po ukazaniu się encykliki Humanae vitae latem 1968 roku miała miejsce równie gorąca dyskusja. Jednak dziś scenariusz jest w jakimś sensie przeciwny, są w nim bowiem bardziej skomplikowane punkty sporne. W tamtym czasie nauczanie doktryny moralnej było dobrze zdefiniowane przez Magisterium, obecny był także „front” kontestacji w imię odnowy (aggiornamento) etyki małżeńskiej; dziś zaś widać zaproszenie papieża do otwarcia duszpasterskiego, co dało początek konfliktowi interpretacji zarówno na poziomie praktycznym, jak i teoretycznym, z formalną prośbą ze strony niektórych kardynałów, skierowaną do papieża, o „wyjaśnienie”.

Należy najpierw zrozumieć fundamentalną troskę, która doprowadziła papieża Franciszka do zwołania dwóch Synodów Biskupów, a potem do napisania tego dokumentu: to odnowa duszpasterstwa rodzin Kościoła w taki sposób, by dotrzeć do wszystkich rodzin, szczególnie tych poranionych, aby je przyjąć (accogliere), towarzyszyć im (accompagnare) i zintegrować je z życiem Kościoła (integrare). Łączy się ona z koncepcjami nawrócenia duszpasterskiego i „dynamizmu wyjścia misyjnego”, poruszonymi w innej adhortacji Evangelii gaudium ( $\mathrm{nr} 20)$.

Wskazanie papieża dla teologii moralnej jest następujące: nie powinna ona prezentować nauczania etycznego poza jego kontekstem znaczeniowym, nie powinna też wiązać się zbytnio z aspektami drugorzędnymi, ale w jej centrum należy umieścić samo serce przekazu Jezusa, to znaczy głoszenie miłosierdzia, które byłoby największą ze wszystkich cnót (EG, nr 34). Franciszek wyznaje, że preferuje „raczej Kościół poturbowany, poraniony i brudny, bo wyszedł na 
ulice, niż Kościół chory z powodu zamknięcia się i wygody kurczowego przywiązania do własnego bezpieczeństwa" (EG, nr 49).

Jeśli spojrzymy na panoramę debaty po ukazaniu się adhortacji Amoris laetitia, trudno jest zaprzeczyć, że sytuacja zarówno duszpasterstwa, jak i teologii moralnej nie jest dziś „,poturbowana, poraniona i brudna”. Widzimy poszczególnych biskupów i konferencje episkopatów, którzy wypowiadają swoje zdanie w odmienny sposób; teologów i świeckich, którzy z surowością tonów prowadzą publiczną debatę za pomocą publicznych apeli, podczas gdy nie ma pewności, że wszystko to doprowadziło albo doprowadzi do odnowy gorliwości duszpasterskiej.

\section{Konflikt interpretacji i wymóg jasności}

Chociaż zarówno sam papież, jak i większość komentatorów nawołuje i podkreśla, że nie powinno się skupiać jednostronnie na kwestiach kazuistycznych, a w szczególny sposób na vexata quaestio dopuszczenia rozwiedzionych ,żyjących w nowych związkach” (albo żyjących nieformalnie) do sakramentów, trudno jednak zaprzeczyć, że właśnie na tym skupiła się uwaga wszystkich. Nie jest przejawem hipokryzji stwierdzenie, że ten konkretny punkt jest rzeczywiście papierkiem lakmusowym owej zmiany nastawienia, przez niektórych wyczekiwanej jako epokowa rewolucja w Magisterium, aby nadgonić ostatnie 200 lat spóźnienia w nowoczesności, przez innych zaś przyjmowana jest $\mathrm{z}$ obawą jako zgubne zerwanie z niezmienną tradycją Kościoła. Właśnie od tego konkretnego punktu rozdziału VIII chciałbym poprowadzić moją myśl, poszerzając ją o bardziej fundamentalne wyzwania dla teologa moralisty.

Wobec wachlarza rozbieżnych i sprzecznych interpretacji trudno zaprzeczyć, że Amoris laetitia nie jest tekstem głęboko ambiwalentnym w tym właśnie decydującym punkcie ${ }^{1}$. Obowiązująca dyscyplina Kościoła, która wyklucza z rozgrzeszenia sakramentalnego i Eucharystii tego, kto będąc związanym ważnym i nierozerwalnym węzłem sakramentalnym i żyjąc w drugim związku, nie podejmuje życia ,jak brat i siostra” w abstynencji od współżycia seksualnego, jest oparta na solidnych motywach porządku wynikającego z Biblii, Tradycji i Magisterium. Została ona jasno wyłożona przez św. Jana Pawła II w Familiaris consortio (nr 84) oraz przez papieża Benedykta XVI w Sacramentum caritatis (nr 29). W żadnej zaś części posynodalnej adhortacji Franciszka nie zostaje wyraźnie potwierdzone, że dziś mogłoby być możliwe

\footnotetext{
${ }^{1}$ Należy ponadto zauważyć, że poza wnioskami praktycznymi wśród zwolenników innowacyjnej praktyki można wyszczególnić rozbieżne, a nawet sprzeczne argumentacje.
} 
wprowadzenie przeciwnej praktyki. Taka jasna i pozbawiona wątpliwości deklaracja o niezaprzeczalnej randze doktrynalnej byłaby per se konieczna, aby pozwolić na tak istotną zmianę dla życia Kościoła.

Jest jednak prawdą, że w Amoris laetitia nie zostaje nawet potwierdzone poprzednie nauczanie. Wręcz przeciwnie, znajdują się tam dwa przypisy, zwłaszcza przypis 336 i 351, które wydają się uznawać zmianę dyscypliny. To właśnie te przypisy cytują zwolennicy nowatorskiej interpretacji dla poparcia swoich tez. Pierwszy z nich, wskazujący, że „konsekwencje lub skutki danej normy niekoniecznie muszą być takie same" (AL, nr 300), odnosi się do możliwości, według której konieczne rozeznanie (discernimento) w kontekście dyscypliny sakramentalnej może skutkować rozpoznaniem, że w konkretnej sytuacji nie ma ciężkiej winy. Drugi zaś przypis, nr 351, mówi o pomocy sakramentów, która mogłaby być zaoferowana także dla tego, kto znajduje się w obiektywnej sytuacji grzechu, a jednocześnie kto mógłby żyć w łasce Bożej, nie będąc subiektywnie winnym. Jeśli chodzi o przypis 336, należy przede wszystkim zauważyć, że to, co zostało ustalone w Familiaris consortio (nr 84) i Sacramentum caritatis ( $\mathrm{nr} 29$ ), nie zależy od oceny winy subiektywnej, ale od obiektywnej sprzeczności na poziomie koherencji sakramentalnej. W związku $\mathrm{z}$ tym to, co zostało powiedziane w przypisie, może być odniesione tylko do kościelnych norm dyscypliny, takich jak zdolność do bycia chrzestnymi czy lektorami itd., ale nie do norm prawa Bożego, jak tych dotyczących natury sakramentów. Na przykład, ogólnie wymieniona tutaj zasada może być zastosowana do kościelnej normy, dotyczącej możliwości przystępowania do Komunii eucharystycznej, niepoprzedzonej spowiedzią sakramentalną, w przypadku niemożności fizycznej lub moralnej dla jej zrealizowania; nie można jej jednak zastosować do zasady boskiej, stąd chrzest jest konieczny, aby przyjąć Eucharystię.

Przypis nr 351 mówi o możliwości zaoferowania „także pomocy sakramentów" dla tych, którzy żyją w obiektywnej sytuacji grzechu, będąc jednak subiektywnie w łasce Bożej. Także w tym przypadku zasada ta ma charakter ogólny, ale i tym razem nie można jej zastosować do kwestii rozwiedzionych, żyjących w powtórnych związkach, ponieważ w ich wypadku nie jest to jedynie problem indywidualnej sytuacji stanu łaski, ale jawna sprzeczność ich życia w wymiarze publicznym i sakramentalnym w stosunku do Eucharystii, jak wyraźnie stwierdza KPK, kan. $915^{2}$. Zresztą, można również powiedzieć, że „pomoc sakramentów” zostaje zaproponowana już od początku

\footnotetext{
${ }^{2}$ Mając charakter generalny, przywołana zasada nie precyzuje, czy chodzi o sytuację zamanifestowaną i uporczywą, a więc warunki istotne według kan. 915 KPK, by nie przystępować do Eucharystii. Nie wspomina się także szczególnej kwestii rozwiedzionych, żyjących w nowych związkach, to znaczy obiektywnej sprzeczności między dwoma sakramentami, która jest argumentowana właśnie w Familiaris consortio (nr 84) i Sacramentum caritatis (nr 29).
} 
drogi towarzyszenia, ponieważ pojednanie sakramentalne jest procesem, który rozpoczyna się od pierwszej rozmowy z księdzem, nawet jeśli może zakończyć się rozgrzeszeniem tylko wtedy, gdy jest wyrażona skrucha i zamiar zmiany życia, który ustawia penitenta w harmonii z prawdą miłości, zgodnie z nierozerwalnym węzłem, który łączy go z małżonkiem.

Wielość interpretacji, które są nie do pogodzenia, jest źródłem zamieszania nade wszystko wśród biskupów i kapłanów. Rzeczywiście, jeśli może ona prowokować ciekawe dyskusje i pogłębienie na płaszczyźnie teologicznej, to dla konkretnego duszpasterstwa przynosi zamęt i szkody. To, co jest dozwolone na Malcie albo w Niemczech, nie jest już dozwolone w Filadelfii albo w Polsce. Słynne już Dubia, zaproponowane Ojcu Świętemu przez niektórych kardynałów, a następnie podjęte przez biskupów i teologów z użyciem tradycyjnej i pełnej szacunku formuły, podkreśliły uzasadnione obawy co do zgodności niektórych interpretacji Amoris laetitia z Magisterium Kościoła, a w szczególności z encykliką Veritatis splendor św. Jana Pawła II, która niestety nie jest ani razu cytowana w tekście posynodalnej adhortacji. Mowa tutaj o nieuniknionych pytaniach o spójność tych interpretacji z podstawowymi zasadami moralnymi i doktryną sakramentalną.

Odpowiedź udzielona przez kard. Waltera Kaspera, że Amoris laetitia nie zmienia doktryny, ale raczej paradygmat („,Ein Paradigmwechsel ändert nicht die bisherige Lehre" - Kasper 2016, s. 723-732) ${ }^{3}$ i że dokonywałoby się to z jednej strony poprzez odkrycie moralności cnót Tomasza z Akwinu, a z drugiej poprzez rozwijanie nauki św. Jana Pawła II, pozostając całkowicie do zweryfikowania co do ogólnej prawdziwości, na płaszczyźnie dyskusji wydaje się zwykłą sztuczką (éscamotage), która pozostawia całkowicie otwartą kwestię sprzeczności między wcześniej pomijaną praktyką dyscypliny sakramentalnej (i to właśnie w Magisterium wielkiego papieża Polaka, opartym na bazie myśli tomistycznej), dziś zaś przyjętą.

W ten sposób zarysowuje się pierwsze zadanie teologa moralisty, który w służbie duszpasterstwu jest wezwany, aby rozjaśniać zasady interpretacyjne dokumentu, podając jego spójną hermeneutykę przynajmniej na trzech poziomach. Po pierwsze, jest to wewnętrzna spójność ambiwalentnych punktów z fundamentalnymi zasadami samej Amoris laetitia, która wzywa, by rozwijać duszpasterstwo nierozerwalnej „więzi” małżeńskiej (AL, nr 211), i zaprasza, by fundamentem była prawda miłości, o czym mówi św. Paweł w 1 Kor $13^{4}$. Wbrew temu, o co prosili pewni teolodzy w okresie międzysynodalnym, mówiąc o swoistym założeniu zmiany dyscyplinarnej (por. Bozzolo i in. 2015;

\footnotetext{
${ }^{3}$ W tym samym duchu zostaje to bardziej wyartykułowane w: Schockenhoff 2017, s. 147-158.

${ }^{4}$ Por. rozdział IV AL, w sposób szczególny nr 90; por. także AL, n. 294, gdzie jest mowa o ,pragnieniu prawdziwej miłości” w sercu osoby.
} 
w szczególności por. wystąpienia E. Schockenhoffa, w których powtarza tezy swojej książki: Schockenhoff 2011), adhortacja potwierdziła jedność między kontraktem a sakramentem małżeństwa (por. AL, nr 75, gdzie cytowana jest doktryna trydencka według KPK) oraz nierozerwalność węzła (por. AL, nr 62). Po drugie, powinna być respektowana zasada spójności z procesem synodalnym, który nie zmienił eucharystycznej dyscypliny Kościoła: na bazie publicznej debaty w Auli oraz wniosków z grup (circoli) możemy nawet powiedzieć, że ojcowie synodalni odrzucili pewne propozycje $w$ tym względzie, obecne w dokumentach przygotowawczych, i powstrzymali się od wyrażenia nadziei takiej zmiany do tego stopnia, że Relatio finalis drugiego zgromadzenia zwyczajnego w 2015 roku nawet nie wspomina o Eucharystii, kiedy traktuje o sytuacjach trudnych. Wreszcie, po trzecie, tekst powinien być przede wszystkim odczytywany zgodnie z Magisterium Kościoła, tym dawnym i najnowszym. Kardynał Gerhard Müller, prefekt Kongregacji Nauki Wiary, w oświadczeniu z 1 grudnia 2016 roku dla austriackiej agencji katolickiej, potwierdził, że respektując decyzję papieża Franciszka nieodpowiadania na $D u$ bia, w każdym przypadku ,ten dokument [Amoris laetitia, red.] nie powinien być interpretowany w taki sposób, aby wskazywać, że wcześniejsze wypowiedzi papieży i Kongregacji Nauki Wiary nie są już obowiązujące”.

\section{Kwestie podstawowe dotyczące tematu}

Wychodząc od konkretnego tematu duszpasterskiego przystępowania do sakramentów przez osoby rozwiedzione żyjące w nowych związkach, można określić kilka istotnych podstawowych kwestii, stojących w centrum konfliktu interpretacji rozdziału VIII posynodalnej adhortacji. Moim zdaniem, chodzi tutaj o punkty doktrynalne o decydującym znaczeniu dla Kościoła, które były już obecne w dyskusji nie tylko w ostatnich czasach, ale teraz ponownie pojawiły się z wielką zapalczywością. Teolog moralny powinien z pewnością skupić się na ich wszystkich implikacjach, ponieważ „katolicki” charakter teologii zakłada charakter organiczny prawdy, w której tout se tient. Wspomnę tutaj jedynie pobieżnie trzy aspekty.

a) Po pierwsze, według mnie, decydujący jest temat związku między doktryną, liturgią i życiem. Wielu interpretatorów, popierających linię zerwania dyscyplinarnego, spieszy z zapewnieniem, że chodzi tutaj o zmianę, która wpłynęłaby jedynie na duszpasterstwo, ale nie dotknęłaby w żaden sposób doktryny. Doktryna zostaje zatem w ten sposób przeniesiona do muzeum skarbów cennych, ale niemających wpływu na życie, podczas gdy praktyka pastoralna byłaby wolna w kształtowaniu swoich wymagań uzależnionych od zmieniających się czasu i ludzi, nie będąc skrępowaną przez zbyt surowe więzy. Jednak 
czy taka jest właśnie katolicka idea „doktryny”? Wiara Kościoła zawsze potwierdzała, że istnieje ścisły związek między prawdami wiary i życiem za pośrednictwem liturgii: lex credendi, lex orandi, lex agen$d i^{5}$. W rzeczywistości doktryna Kościoła nie powinna być rozumiana według racjonalistycznej redukcji czy jedynie formuł: jest ona raczej wyznaniem i celebrowaniem wydarzenia, które ze swej natury dąży do wyrażenia się w konkretnym życiu wspólnoty i każdego wierzącego. Duszpasterstwo wykorzenione z nauki objawionej i z liturgii staje się kwestią strategii ludzkich perswazji, zmierzających do osiągnięcia praktycznych celów. Ostatecznie zaś sprowadza się ono do kwestii władzy. Nie powinno być zapewne zlekceważone napomnienie kard. Roberta Saraha, który w owym oddzieleniu doktryny i duszpasterstwa widzi współczesną postać jakiejś wyniszczającej herezji.

b) Druga kwestia, którą należy starannie rozważyć, dotyczy sakramentalności w relacji do sumienia. Niektóre wystąpienia konferencji biskupów (a dokładnie rzecz ujmując biskupów Malty i, pośrednio, także Komitetu Episkopatu Niemiec) potwierdziły, że dostęp do sakramentu Eucharystii powinien być pozostawiony osądowi sumienia każdego człowieka. Nie chodzi tutaj oczywiście o wewnętrzną weryfikację własnej sytuacji przed Bogiem, kiedy to „człowiek baczy na siebie samego" (1 Kor 11,28). To nie jest także sprawa oceny subiektywnej winy grzechów przeszłości. Chodzi tutaj bardziej o osąd albo na temat trwania publicznego, sakramentalnego związku małżeńskiego, albo na temat faktu, czy pozamałżeńskie relacje seksualne, które jawią się jako cudzołóstwo lub przynajmniej jako nierząd, od których nie ma intencji wycofania się, byłyby zgodne lub nie z życiem chrześcijańskim. Tego rodzaju pogląd doprowadza do zranienia ekonomii sakramentalnej Kościoła i jest radykalnym subiektywizmem do tego stopnia, że prawda, którą Kościół naucza jako opartą na boskim objawieniu, miałaby być ostatecznie poddana osądowi sumienia. Kościół nigdy nie mylił forum sakramentalnego z forum sumienia; gdyby tak było, to nie miałyby sensu słowa kapłana, który w imieniu Kościoła mówi: „I ja odpuszczam tobie”. Powinien raczej powiedzieć: „Rozumiem, że twoje sumienie Ci odpuszcza", tak więc sakrament pokuty straciłby jakiekolwiek znaczenie kościelnej obiektywności, jak to jest wśród luteran.

c) Wchodzi tutaj w grę także kwestia relacji między miłosierdziem i cnotami moralnymi. Zgodnie z nauczaniem zdrowej doktryny, potwierdzonej przez Veritatis splendor, wartość moralna czynu, zgodnie

\footnotetext{
${ }^{5} \mathrm{Na}$ ten temat: Granados 2015, s. 35-61.
} 
z wizją św. Tomasza z Akwinu, ,zależy przede wszystkim i zasadniczo od przedmiotu rozumnie wybranego przez świadomą wolę" (nr 78). Reguła i miara działania ma zatem charakter racjonalny w stosunku do celów poszczególnych cnót moralnych. Miłość, która ukierunkowuje ludzkie akty ku ostatecznemu celowi miłości Boga, zakłada tę racjonalną miarę, ale ona sama nie określa charakteru aktu, zastępując się normą cnót moralnych. Innymi słowy, nie jest zadaniem miłości stwierdzenie, czy akt zabijania nieuleczalnie chorego pacjenta byłby eutanazją lub aktem litości; to nie miłość powie mi, czy akt seksualny z osobą inną niż współmałżonek, z którym jestem związany nierozerwalnym węzłem sakramentalnym, nie powinien być ,już więcej” uważany za cudzołóstwo, ale powie mi to akt słusznego uczucia. Miłosierdzie, będące cnotą dlatego, że jest poruszeniem kierowanym przez rozum (S. Th. I-II, q. 30, a. 3), jest podporządkowane miłości i we wspomaganiu nędzy bliźniego musi dać się kierować przez normy cnót moralnych.

\section{Zmiana ,paradygmatu"?}

Nieco dłuższą refleksję chciałbym poświęcić punktowi już zakreślonemu na początku: kwestii zmiany ,paradygmatu” teologii moralnej, do której to zmiany nawoływałaby posynodalna adhortacja Amoris laetitia ${ }^{6}$. Temat zmiany „paradygmatu" (Paradigmenwechsel) w poznaniu został szeroko omówiony przez epistemologa Thomasa S. Kuhna (por. Kuhn 1970, a szczególnie Postscriptum 1969), który definiuje go jako kod przekonan, podzielanych przez społeczność, regulujący język i normatywnie determinujący kontekst semantyczny twierdzeń.

Jest jasne dla wszystkich, że doktryna Kościoła nie jest surowym i niezmiennym systemem formuł, ale jest raczej żyjącym organizmem, który rozwija się podobnie jak ciało. $Z$ takim właśnie szacunkiem odnosi się ona do nauczania Jezusa, ponieważ „Niebo i ziemia przeminą, ale Moje słowa nie przeminą" (Mt 24,35). Refleksja doktrynalna i teologiczna Kościoła nabyła w ciągu wieków zespół pewnych zasad dla zweryfikowania życiowej zgodności tradycji z jej początkami, bez fałszywych dodatków i bez utraty istotnych elementów: eodem sensu, eademque sententia. W szczególności bł. John Henry Newman, wychodząc właśnie ze swojego osobistego doświadczenia,

${ }^{6}$ Jest to już teza podtrzymywana przez wielu, jakoby adhortacja apostolska była epokową zmianą w teologii moralnej. Por.: Goertz, Witting (Hrsg.) 2016; wydanie włoskie zawiera kilka artykułów uzupełniających: S. Goertz, C. Witting (red.), Amoris laetitia. Un punto di svolta per la teologia morale?, A. Autiero (ed. wł.), San Paolo, Cinisello B. (MI), 2017. 
zaprezentował esej o rozwoju doktryny chrześcijańskiej (por. Newman 1989), pokazując, w jaki sposób definiuje ona przestrzeń i ustawia rytm czasu. Innymi słowy: nie chodzi tutaj o dostosowanie się do rytmu czasu i pozwalanie na zmienianie się przez mody, aby być zaakceptowanym, ale bardziej idzie o określenie tejże doktryny jako rytmu historii. Jej rozwój, bez negowania wszystkiego, co zostało objawione, pokazuje jej wieczną płodność, podkreślając jej nowe i niezwykłe aspekty w spotkaniu ze światem. Doktryna staje się w ten sposób matrycą nowej historii, jak to zostało potwierdzone właśnie przez pojedyncze wydarzenie wprowadzenia nierozerwalności małżeństwa w obyczaj publiczny i do legislacji społeczeństwa późnego antyku, w którym był praktykowany rozwód7 ${ }^{7}$.

Ażeby uściślić porównanie propozycji Kaspera i myśli Newmana, należy zauważyć, że ów błogosławiony określa jako „nuty” ciągłości doktryny zarówno preservation of the type (pierwsza nuta), jak i continuity of principles (druga nuta). Typem, rodzajem (type) byłoby to, co Kasper nazywa ,paradygmatem", odróżnionym od zasad. Powinniśmy jednak pamiętać, że dla Newmana, zarówno type, jak i principles muszą być zachowane, nawet więcej, typ (type) jest bardziej rozstrzygający od samych zasad, ponieważ zawiera podstawową formę Idei chrześcijańskiej w ciągu czasu. W przypadku zaproponowanym przez Kaspera zmiana paradygmatu byłaby nie herezją wobec jakiegoś konkretnego punktu doktryny, ale właśnie półherezją, która zakłóca samą istotę wiary i życia chrześcijańskiego.

Możemy zatem zrozumieć, że idea legalnej zmiany paradygmatu może być zaakceptowana tylko w bardzo ograniczonym sensie i pod warunkiem, że nie podważa się podstawowej formy nauczania moralnego Kościoła. Podajmy przykład. Jeśli znajdujemy się w anglojęzycznym kontekście językowym, termin gift ma bardzo pozytywne i przyjemne znaczenie: oznacza 'dar', 'prezent'. Jeśli jednak zmienimy paradygmat języka i udamy się do Niemiec, tam to samo słowo oznacza 'truciznę'. Czy możemy więc powiedzieć, że zmieniliśmy jedynie paradygmat, a nie samą rzeczywistość, jeśli do leku, wyprodukowanego w Niemczech jako niebezpieczny, przyczepimy etykietę „dar” (gift)? Jeśli w Kazaniu na górze Jezus mówi o „cudzołóstwie” i wskazuje je jako grzech, to czy możemy powiedzieć, że jesteśmy wierni tejże doktrynie, jeśli definiujemy go jako niedoskonałość w stopniowej drodze do ideału, którego moralność jest pozostawiona do osądu każdego indywidualnego sumienia? Jeśli zaś z kolei, aby usprawiedliwić się, sami dojdziemy do stwierdzenia, że „W czasach Jezusa nie było rejestratorów”, które mogłyby nam zagwarantować, że coś naprawdę powiedział albo że dzisiaj On też prawdopodobnie po-

${ }^{7}$ Potwierdza to: D'Avray 2005, s. 206-207. 
zwoliłoby na rozwód na podstawie zasady miłosierdzia ${ }^{8}$, to tym samym my sami niszczymy fundamenty wiary katolickiej, do tego stopnia, że posłuszeństwo następcy Piotra, mocno przywoływane przez innowatorów, pozostałoby także bez żadnych podstaw teologicznych i rzeczywistych.

Numer 300. Amoris laetitia traktuje o potrzebie rozeznania każdej sytuacji, ,przypadek po przypadku”. W jakim więc sensie zaprasza nas to do zmiany w teologii moralnej paradygmatu, który nie zdradziłby tradycji Kościoła i nie zniweczył objawienia, zawartego w słowie Jezusa? Okres nowoczesnej kazuistyki wraz z bogactwem subtelnego, indukcyjnego podejścia, również ukazał pewne bezdroża zgubne dla moralności chrześcijańskiej (por. Jonsen, Toulmin 1988). Pomimo nadmiernego tonu polemicznego Pascal w swoich Provinciales ostro podkreślił śmiertelne niebezpieczeństwo tej legalistycznej mentalności, która poprzez zdolność subtelnego rozumowania ludzkiego niweczy przykazanie Boga (por. Mk 7,8): Ecce patres qui tollunt peccata mundi (por. Cariou 1993).

Encyklika św. Jana Pawła II Veritatis splendor pozostaje nieodwołalnym punktem Magisterium dla przezwyciężenia zagrożeń arbitralnej kazuistyki i subiektywistycznej etyki sytuacyjnej. W sposób autorytatywny określiła ona graniczne kryterium weryfikacji zgodności ze „zdrową nauką”: jest nim „ponowne stwierdzenie powszechności i niezmienności przykazań moralnych, a w szczególności tych, które bez wyjątku i zawsze zakazują czynów wewnętrznie złych” (nr 115). Odrzuciła ona również ideę ,podwójnego statusu prawdy moralnej”, dlatego „ujęcie to, uwzględniające okoliczności i sytuację, mogłoby dostarczać uzasadnień dla wyjątków od reguły ogólnej i tym samym pozwalać w praktyce na dokonywanie z czystym sumieniem czynów, które prawo moralne uznaje za wewnętrznie złe" (nr 56). Odrzuciła ona także - jako sprzeczną z doktryną Kościoła - „twórczą interpretację sumienia moralnego" (nr. 54 i następne). Troska o ludzi i duszpasterskie nawrócenie teologii moralnej nie mogą oznaczać rezygnacji z doktryny o absolutności negatywnych norm moralnych, zawsze i bez wyjątku zakazujących aktów, które z uwagi na przedmiot są „wewnętrznie złe”. To także nie może oznaczać powrotu do modelu kazuistycznego, przeciwstawiającego prawo sumieniu, na podstawie woluntarystycznego nominalizmu, który pozbawia prawo wszelkiej treści na temat dobra i rozumie je jako arbitralny i zmienny wyraz intencji ustawodawcy boskiego lub ludzkiego.

${ }^{8}$ Chodzi tutaj o: odnośne twierdzenia Przełożonego Generalnego Towarzystwa Jezusowego o. Arturo Sosa Abascala, wywiad G. Rusconiego na stronie www.rossoporpora.org, umieszczonego potem w wersji czasopisma Autora w "Il giornale di Lugano" z dn. 18 lutego 2017 r., oraz jezuity amerykańskiego o. Thomasa Reese, What God has joined, „National Catholic Reporter”, 6 aprile 2017. 
Papież Franciszek w adhortacji Amoris laetitia zaprasza nas do zrobienia kroku do przodu, a nie kroku wstecz. Chodzi tutaj nie o powrót do kazuistyki, ale o rozwój teologii moralnej, która wie, w jaki sposób skorzystać z pedagogicznego wymiaru drogi naśladowania Chrystusa, charakteryzującego się w sposób wyraźny prymatem łaski.

Zmiana paradygmatu w odniesieniu do legalistycznej i dedukcyjnej wizji moralności była już popierana i wskazana w Veritatis splendor (por. nr 78), która jednak wyraziła jednocześnie graniczne kryterium, tak aby nie wpaść w zmianę formy (type) moralności katolickiej, która wynaturzyłaby substancję w zerwaniu ze „zdrową nauką” (2 Tm 4,3). Spójność z tą encykliką św. Jana Pawła II, a więc szacunek dla jądra jego nauczania, a mianowicie dla istnienia kryterium granicznego $\mathrm{w}$ absolutności negatywnych norm moralnych, które bez wyjątku zabraniają czynów wewnętrznie złych, nie jest tylko gwarancją ciągłości z Tradycją naszej interpretacji Amoris laetitia. Jest to również warunek, aby nie wrócić do przeszłości, do kazuistycznej czy subiektywistycznej moralności, jak i warunek realizacji fundamentalnej troski, wyrażonej przez papieża Franciszek, dotyczącej duszpasterskiego towarzyszenia najbardziej oddalonym, słabym i grzesznikom, w prawdzie miłości.

\section{Centralność kwestii edukacyjnej dla teologii moralnej}

Zmierzając do końca mojej wypowiedzi, chciałbym wyjaśnić ostatnią wzmiankę, powołując się na niezwykle ostre wskazanie i aktualną wskazówkę kard. Jean-Marie Lustigera, na temat stopniowości, w kontekście posynodalnej adhortacji apostolskiej Familiaris consortio (Lustiger 1982, s. 31-57). Jego główny argument można streścić następująco: wykluczenie stopniowości prawa jest warunkiem możliwości prawa stopniowości. Oznacza to, że tylko w przypadku zachowania wartości obowiązkowości, a nie jedynie ,idealności” (,ideału”) przykazania Bożego, jest możliwa pedagogika stopniowości towarzyszenia, oparta na łasce i nawróceniu.

Aktualizując tę argumentację, moglibyśmy powiedzieć, że jedynie taka interpretacja Amoris laetitia, która w wierności poprzedniemu Magisterium zachowuje wartość wiążącą tradycyjnej praktyki, jest w stanie umocować tę postawę duszpasterską towarzyszenia, którą papież Franciszek poleca pasterzom Kościoła i którą teologia moralna ma za zadanie wspierać. Interpretacje pobłażliwe zamierzają rozwiązać problemy integracji sytuacji „nieregularnych" poprzez zmianę normy i dyscypliny. W rzeczywistości, takie działanie, jedynie pozornie miłosierne, nie jest działaniem duszpasterskim, ale jest raczej aktem prawnym, który czyni zbędną opiekę duszpasterską (na ten temat zob. Granados, Kampowski, Pérez-Soba 2016). 
Teologia moralna odpowiadająca na wyzwania stawiane przez Amoris laetitia i nawrócenie duszpasterskie, o które prosi papież Franciszek, będzie musiała jednomyślnie rozwijać doktrynę Veritatis splendor na linii centralności kwestii edukacji dla moralności. Zaznaczam tutaj telegraficznie cztery linie rozwoju:

a) Nade wszystko zaleca się perspektywę c nót, prowadzącą do odtworzenia chrześcijańskiego podmiotu moralnego; chodzi tutaj o umieszczenie siebie w perspektywie podmiotu działającego, według wskazania Veritatis splendor ( $\mathrm{nr} 78$ ) do formowania w prawdzie i w uczuciach, a nie z punktu widzenia obserwatora zewnętrznego, który osądza lub potępia działania.

b) W tę właśnie wskazaną wyżej linię wpisuje się słuszne rozumienie praktycznej racjonalności i roztropności, które św. Tomasz z Akwinu docenił w dojrzałym stadium swojej myśli etycznej (por. Abbà 1983). Ta cnota nie działa przez zastosowanie ogólnych zasad do wielu przypadków, zgodnie z metodologią chylącej się ku upadkowi kazuistyki, albo też przez dedukcję od prawdy metafizycznej typu spekulacyjnego, jak nauczała neoscholastyka; ona potrafi bardziej konkretnie wyszukać najbardziej adekwatne działanie do realizacji veritas practica, na mocy wspólnej natury podmiotu z dobrem, gwarantowanej przez inne cnoty moralne.

Jednakże „prawda podmiotowości”, którą wyraża tomistyczna doktryna o roztropności, nie może być mylona z hermeneutyką relatywistyczną, jak to się dzieje na przykład w arystotelesowskiej etyce „fronesis”, którą proponuje Hans Georg Gadamer na bazie szóstej księgi Etyki Nikomachejskiej (Gadamer 2001). Akwinata rzeczywiście stwierdza, że rozum praktyczny ma uniwersalny wymiar prawdy, dlatego przedmiot aktu może być uznany już sam w sobie za zły, z pominięciem rozpatrzenia okoliczności i subiektywnych intencji.

W komentarzu do etyki Arystotelesa wielokrotnie powraca spostrzeżenie, że nie wszystkie działania człowieka są podatne na właściwą metodę, środek, który zmierzałby do roztropności (Sententia Libri Ethicorum II, 7, 143-145; zob. Melina 2005, s. 121, o tym samym także: Rhonheimer 1994, s. 530-592). Istnieją więc rzeczywiście takie czyny, które zakładają już w swej nazwie pewne zło: takie działania są złe same w sobie, a nie dlatego, że obejmują jakiś nadmiar lub brak. Dlatego w ich wypadku nie jest możliwy przypadek, w którym ktoś, wypełniając je, działałby słusznie, wręcz przeciwnie, czyniąc je, zawsze popełnia się grzech. Jest znaczące, że św. Tomasz wspomina tutaj właśnie przypadek cudzołóstwa, które wśród greckich komentatorów Arystotelesa było przedmiotem dyskusji jako ewentualny wyjątek, usprawiedliwiony w okolicznościach, w których mogłoby ono służyć ocaleniu ojczyzny. 
c) Życie moralne ludzi potrzebuje sprzyjającego środowiska, a zatem etyka potrzebuje ,etosu”, podzielanego w jakiejś społeczności czy kulturze, nawet jeśli jest ona mniejszościowa. Może być w tym kontekście przydatna i skuteczna idea „praktyk dobrego życia”, gdzie w grę wchodzi charakter wspólnotowy życia moralnego i potrzeba mediacji kultury środowiskowej dla kształtowania moralnego charakteru podmiotu9 9

d) W końcu, wymiarem oryginalnym i fundamentalnym jest rozpoznanie chrystocentrycznego charakteru chrześcijańskiego życia moralnego, a więc także prymatu łaski, która wspiera zarówno niezbędne i ciągłe nawrócenie, jak i stopniowy wzrost w miłości.

Papież Franciszek skierował do Kościoła wezwanie, aby zwrócić uwagę na rodziny kruche, zranione, naznaczone materialnym i duchowym ubóstwem. Należy jednak nauczyć się patrzeć na dramaty i nędze ludzkie oczami wiary, która widzi w perspektywie odkupienia Chrystusa i z tego powodu nie rezygnuje i nie dostosowuje prawa do miary po ludzku przewidywalnych możliwości. Święty Jan Paweł II w encyklice Veritatis splendor ostrzegł nas przed tą ostatecznie pelagiańską pokusą: ,Tylko w tajemnicy Chrystusowego Odkupienia ukryte są «konkretne» możliwości człowieka" (nr 103). Tak, taka jest właśnie stawka teologii moralnej: rzeczywistość odkupienia w Chrystusie, ut non evacuetur Crux Christi (1 Kor 1,17).

\section{LE SFIDE DI “AMORIS LAETITIA” PER UN TEOLOGO DELLA MORALE}

\section{SOMMARIO}

L'ambivalenza di alcune formulazioni del cap. VIII dell'esortazione apostolica Amoris laetitia e il conseguente conflitto delle interpretazioni in atto nella Chiesa, pongono al teologo moralista una sfida senza molti precedenti. Solo un'interpretazione coerente con la Tradizione dottrinale e in particolare con il magistero di san Giovanni Paolo II in Familiaris consortio e in Veritatis splendor, è in grado di onorare l'intenzione profonda che ha animato Papa Francesco: l'attenzione pastorale per le famiglie "ferite" e "lontane". La risposta alle attese dell'esortazione apostolica non consiste dunque in un "cambio di paradigma", che introduca eccezioni "caso per caso", ma piuttosto nell'impegno di ricostruzione del soggetto morale cristiano e dunque della questione educativa nella prospettiva delle virtù, in coerenza con le esigenze della razionalità pratica e del primato della grazia.

\footnotetext{
${ }^{9} \mathrm{Na}$ ten temat por. refleksję A. McIntyre’a w drugiej części jego dzieła: McIntyre 1985. Co do aplikacji w rodzinie zob. publikację: Kampowski (red.) 2017.
} 


\section{CHALLENGES OF AMORIS LAETITIA \\ FOR A MORAL THEOLOGIAN}

\section{SUMMARY}

The ambivalence of some formulations in Chapter VIII of the Apostolic Exhortation Amoris laetitia and the resulting conflict of interpretations that is currently taking place in the Church pose an almost unprecedented challenge for the moral theologian. Only one interpretation consistent with doctrinal Tradition, and in particular with the Magisterium of Saint John Paul II in Familiaris consortio and Veritatis splendor, is capable of honoring the profound intention that motivated Pope Francis: pastoral care for "wounded" and "distant" families. The response to the expectations of the Apostolic Exhortation therefore does not depend on a "paradigm shift" that would introduce exceptions "on a case-by-case basis," but rather on the task of reconstructing the Christian moral subject and therefore in the educational question from the perspective of the virtues, in a way consistent with the demands of practical reason and of the primacy of grace.

Słowa kluczowe: Amoris laetitia; rozwiedzeni żyjący w powtórnych związkach; „zmiana paradygmatu” (Paradigmenwechsel); doktryna i duszpasterstwo; stopniowość

Keywords: Amoris laetitia; divorced and remarried; „paradigm shift” (Paradigmenwechsel); doctrine and pastoral care; the law of graduality

\section{BIBLIOGRAFIA}

Abbà G. (1983), Lex et virtus. Studi sull'evoluzione della dottrina morale di san Tommaso d'Aquino, Roma.

Bozzolo A., Chiodi M., Dianin G., Sequeri P., Tinti M. (2015), Famiglia e Chiesa un legame indissolubile. Contributo interdisciplinare per l'approfondimento sinodale, Città del Vaticano.

Cariou P. (1993), Pascal et la casuistique, Paris.

D'Avray D. (2005), Medieval Marriage: Symbolism and Society, Oxford.

Gadamer H.G. (2001), Das hermeneutische Problem und die aristotelischen Ethik, in: Das Problem des historischen Bewußtsein, üb. T.N. Klass, Tübingen.

Goertz S., Witting C. (Hrsg.) (2016), Amoris laetitia - Wendepunkt für Moraltheologie?, Freiburg.

Granados J. (2015), Eucaristia e divorzio: cambia la dottrina?, Siena.

Granados J., Kampowski S., Pérez-Soba J.J. (2016), Amoris laetitia. Accompagnare, discernere, integrare. Vademecum per una nuova pastorale familiare, Siena.

Jonsen A.R., Toulmin S. (1988), The Abuse of Casuistry. A History of Moral Reasoning, Berkeley. Kampowski S. (a cura di) (2017), Pratiche di vita buona per una cultura della famiglia, Siena.

Kasper W. (2016), „Amoris laetitia”: Bruch oder Aufbruch. Eine Nachlese, „Stimmen der Zeit” 11, s. $723-732$.

Kuhn T.S. (1970), The Structure of Scientific Revolution, Chicago. 
Lustiger J.M. (1982), Gradualità e conversione, in: AA.VV., La "Familiaris consortio", Città del Vaticano, s. 31-57.

McIntyre A. (1985), After Virtue. A Study in Moral Theory, $2^{\circ}$ edition, London.

Melina L. (2005), La conoscenza morale. Linee di riflessione sul Commento di san Tommaso all'Etica Nicomachea, $2^{\circ}$ edizione, Milano, 121 ( $1^{\circ}$ edizione: Città nuova, Roma 1987).

Newman J.H. (1989), An Essay on Development of Christian Doctrine, Notre Dame.

Rhonheimer M. (1994), Praktische Vernunft und Vernunftigkeit der Praxis. Handlungstheorie bei Thomas von Aquin in ihrer Entstehung aus dem Problemkontext der aristotelischen Ethik, Berlin.

Schockenhoff E. (2011), Chanchen zur Versöhnung. Die Kirche und die wiederverheirateten Geschiedenen, Freiburg.

Schockenhoff E. (2017), Traditionsbruch oder notwendige Weiterbildung? Zwei Lesearten des Nachsynodalen Schreibens „Amoris laetitia”, „Stimmen der Zeit” 3, s. 147-158.

Valadier P. (2013), Rigorisme contre liberté morale. Les Provinciales : actualité d'une polémique antijésuite, Bruxelles.

Tłumaczenie: Wojciech Kućko

Livio Melina - (ur. 1952 r.) kapłan diecezji Adria, teolog włoski, profesor teologii moralnej w Papieskim Instytucie Jana Pawła II dla Studiów nad Małżeństwem i Rodziną w Rzymie, którego rektorem był w latach 2006-2016. Visiting Professor w Waszyngtonie (DC) w Stanach Zjednoczonych oraz w Melbourne w Australii, członek Papieskiej Akademii Teologicznej, redaktor naczelny czasopisma „Anthropotes”. Autor licznych książek i publikacji z zakresu teologii moralnej fundamentalnej, etyki seksualnej i małżeńskiej oraz bioetyki.

Livio Melina (Adria, 1952), sacerdote diocesano e professore ordinario di Teologia morale presso il Pontificio Istituto Giovanni Paolo II per Studi su Matrimonio e Famiglia di Roma, di cui è stato anche Preside dal 2006 al 2016. a Washington DC (USA) e Melbourne (Australia), membro della Pontificia Accademia di Teologia, Direttore della rivista „Anthropotes”. Autore di numerosi libri e pubblicazioni nell'ambito della teologia morale fondamentale, dell'etica sessuale e coniugale e della bioetica. 